\title{
Novitates Gabonenses 72. Haplocoelum gabonicum (Sapindaceae), a new species from Gabon and adjacent Congo
}

\section{F. J. Breteler}

Summary. The new species Haplocoelum gabonicum Breteler (Sapindaceae) from Gabon and adjacent Congo is described and illustrated. Morphologically it is most similar to H. acuminatum Radlk. ex Engl. and H. congolanum Hauman. It differs from these species by foliar characters such as the non-alate rachis, the presence of a rudimentary lower pair of leaflets, and the entire acumen of its leaflets. These differences are summarised in a key. $H$. congolanum is synonymised under $H$. acuminatum. The latter species is lectotypified and its authorship corrected.

Key Words. Africa, conservation status, Congo (Brazzaville), taxonomy.

\section{Introduction}

The genus Haplocoelum (Sapindaceae) is restricted to Africa with 13 species described from continental Africa and two from Madagascar. One of these two, H. alatum, published by Radlkofer in 1933 with some doubt, was transferred by Capuron (1969) to another genus and became Doratoxylon alatum (Radlk.) Capuron. In the same paper Capuron added a new species from Madagascar, $H$. perrieri Capuron. A recent molecular study of the Sapindaceae (Buerki et al. 2009), with two samples of H. foliosum (Hiern) Bullock from the African continent and one of $H$. perrieri, demonstrated the polyphyly of the genus with $H$. perrieri belonging to a genus other than the continental african Haplocoelum. The polyphyly shown in an earlier molecular study (Harrington et al. 2005) is most likely due to a misidentification of Edwards KE501, because the name $H$. gallaense (Engl.) Radlk. mentioned for this specimen is a synonym of $H$. foliosum (Verdcourt 1998), the other species investigated. Haplocoelum is mainly confined to East, Central, and South tropical Africa. Verdcourt (1998) reduced some species to synonymy or to subspecific rank, resulting in the recognition of two species in the Flora of Tropical East Africa. Hauman (1960) recognised five species for the Flore du Congo Belge of which two were described as new (Hauman 1958). Fouilloy \& Hallé (1973) stated that the genus was not present in Gabon, and in Cameroon with one species $H$. gallaense (Engl.) Radlk. only. Nevertheless they produced a key to this and two other species, $H$. dekindtianum (Engl.) Radlk and H. acuminatum Radlk. ex Engl., both originally described from Angola, the former being reduced to a synonym of $H$. foliosum (Hiern) Bullock by Exell \& Mendonça (1954). H. gallaense was also treated as a synonym of $H$. foliosum by Verdcourt (1998).

The Haplocoelum specimens from Gabon, collected before the publication of the Flora treatment by Fouilloy \& Hallé (1973), were not recognised as belonging to this genus and later collections were identified as $H$. acuminatum, most likely with the key published in the aforementioned flora. Comparison of this material with the types of Haplocoelum acuminatum and the morphologically similar $H$. congolanum Hauman revealed that the Gabon specimens belong to a new species, which is described below.

Haplocoelum gabonicum Breteler sp. nov. H. acuminati Radlk. ex Engl. et $H$. congolani Hauman maxime simile, ab ambobus differt rhachidi foliorum non alata, acumen foliolii non lobato et foliolis infimis maxime deminutis. Typus: Gabon, Monts de Cristal, $15 \mathrm{~km}$ NE of Assok, alt. $600-700$ m, 21 Aug. 1978, Breteler E de Wilde 193 (holotypus WAG!; isotypus BR!, K, MA, MO, P, PRE).

http:/ /www.ipni.org/urn:lsid:ipni.org:names:77114305-1

Shrub to small tree up to $15 \mathrm{~m}$ tall and $15 \mathrm{~cm}$ dbh. Branchlets subappressed-puberulous to tomentellous, glabrescent. Leaves paripinnate to imparipinnate, $(1-) 2-$ 7 (-8)- foliolate (the rudimentary, basal pair excluded); petiole \pm semiterete, broadened towards the base, $2-7$ ( -10$) \mathrm{mm}$ long, puberulous, glabrescent; rachis \pm terete (see Fig. 1C), semiterete in the basal part, $(0.5-) 3-10$ $(-13) \mathrm{cm}$ long, puberulous, at the base provided with two narrowly triangular, up to $3 \mathrm{~mm}$ long, puberulous,

\footnotetext{
Accepted for publication November 2011.

1 Herbarium Vadense, Wageningen University, Foulkesweg 37, NL 6703 BL Wageningen, The Netherlands. e-mail: frans@breteler.demon.nl
} 
rudimentary leaflets; leaflets: petiolule usually tumid (1 -) $2-3(-4) \mathrm{mm}$ long, puberulous; lamina papery, glabrous or sometimes with a few sparse hairs on the midrib beneath, elliptic, $2-3.5$ times as long as wide, $(4-) 8-16(-21) \times(2-) 3-5(-8) \mathrm{cm}$, cuneate at base, the margin revolute or not, $0.5-2.5 \mathrm{~cm}$ long acuminate at apex, the acumen acute to rounded apically; midrib and the $(8-) 9-13$ (15) pairs of main lateral nerves as well as the tertiairy nervation prominent both sides. Male inflorescence paniculate, often lowly branched, rarely a simple raceme, up to $5 \mathrm{~cm}$ long, \pm pendulous, greenish white, puberulous-tomentellous,

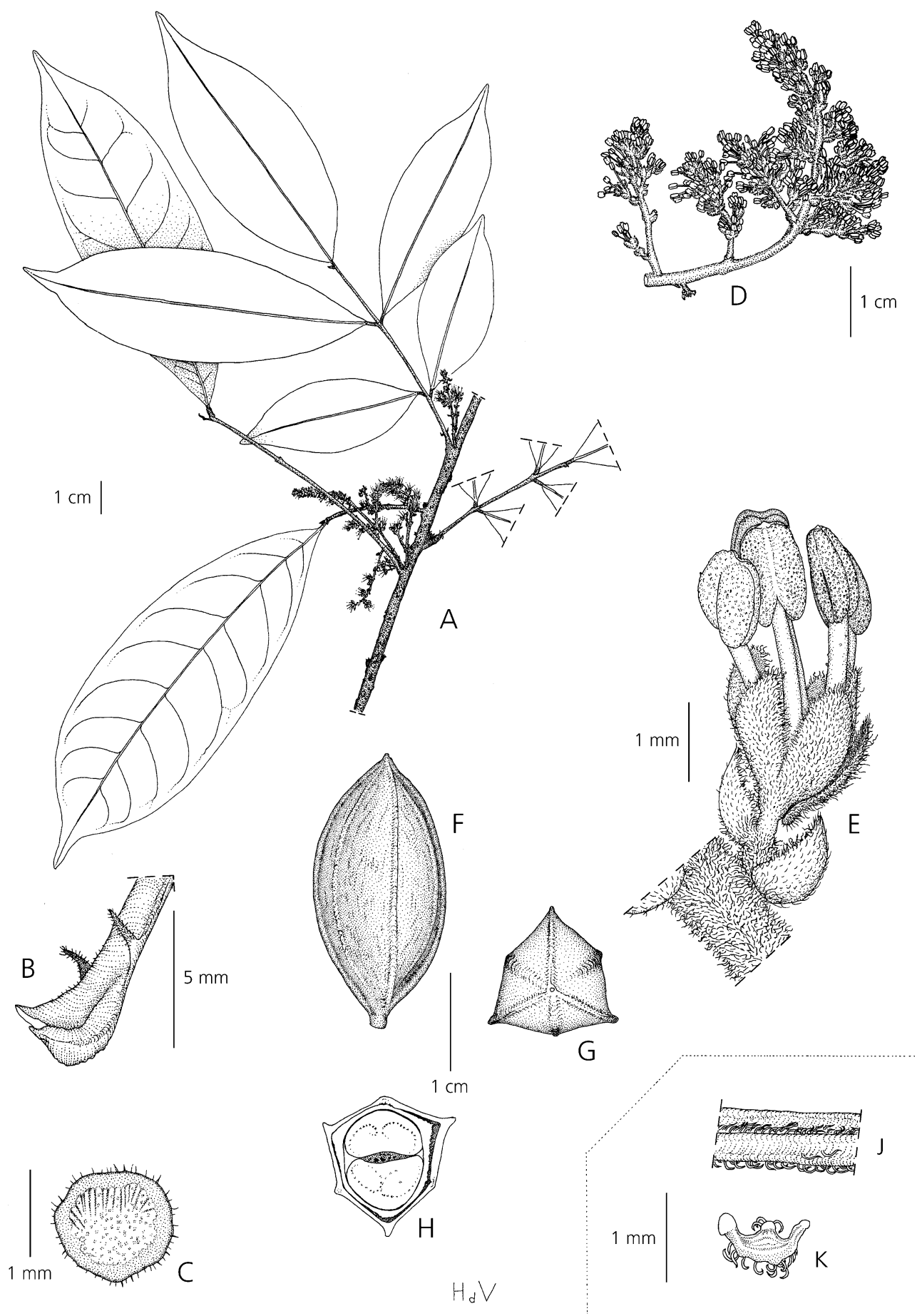

Fig. 1. Haplocoelum gabonicum. A flowering branch; B petiole with basal part of leaf rachis with rudimentary pair of leaflets; $\mathrm{C}$ transverse section of leaf rachis; $D$ inflorescence; $E$ male flower; $F$ fruit; $G$ apical view of fruit; $H$ fruit in transverse section. Haplocoelum acuminatum J part of leaf rachis from above; $\mathrm{K}$ leaf rachis in transverse section. A - $\mathrm{C}$ from MacPherson 16624 (WAG); D, E from Breteler \& de Wilde 193 (WAG); F - H from White 182 (MO); J, K from Marques 210 (LISU). DRAWN BY H. DE VRIES. 
often catkin-like when young. Bracts and bracteoles elliptic, concave, c. $1 \mathrm{~mm}$ long, margin entire or denticulate. Male flowers greenish white, 5 (-6)-merous. Pedicel $1-2 \mathrm{~mm}$ long, puberulous. Sepals $5(-6)$, free, sometimes irregular in size, elliptic, concave, $1-2 \mathrm{~mm}$ long, top acute, puberulous outside, glabrous inside. Petals absent. Stamens 5 (-6), free, glabrous; filaments $2.5-3 \mathrm{~mm}$ long, anthers $1 \mathrm{~mm}$ long. Pistillode sometimes present, $2-3 \mathrm{~mm}$ long, glabrous. Female flowers unknown. Fruits green (mature?), \pm sharply trigonus with slightly convex faces, tapering at both ends, $2.5-3 \times 1.5-1.8 \mathrm{~cm}, \pm$ smooth, glabrous, pruinose, one-seeded, probably dehiscent. Seed ellipsoid c. $2 \times 1.5 \mathrm{~cm}$, slightly triangular on transverse section; cotyledons \pm plano-convex, envelopped in a $1-1.5 \mathrm{~mm}$ thick sarcotesta. Fig. 1A-H.

DISTRIBUTION. Gabon, Congo (Brazzaville). Map 1. SPECIMENS EXAMINED. GABON. $10 \mathrm{~km}$ La Lara-Makokou Rd, along Okana R., 6 Sept. 1978, Breteler $\mathcal{E} \sigma$ de Wilde 448 (BR, P, WAG); 10 km S of Makokou, 27 April 1978, Florence 180 (P); 8 Dec. 1978, Florence 535 (P); 5 April 1978, Florence 825 (P); 7 April 1978, Florence 869 (P); 14 April 1978, Florence 924 (P); 26 April 1978, Florence 1079 (P); Mboumi, 14 Aug. 1999, Isembe 170 (WAG); Ndingui, 16 Sept. 1926, Le Testu 6074 (BR, P, WAG); Nzinganzinga,
8 Oct. 1929, Le Testu 7497 (BR, P, WAG); Navanga, 9 Aug. 1930, Le Testu 8233 (BR, P, WAG); Ngwasso, 13 Sept. 1930, Le Testu 8339 (BR, P, WAG); Bambidie, 13 Sept. 1996, McPherson 16587 (BR, WAG); 13597 (BR, WAG); 18 Sept. 1996, 16624 (BR, P, WAG); Reserve de Lopé-Okanda, 9 Nov. 1990, White (series 2) 182 (MO). CONGo (BRAZZAVILLE). Etoumbi region, $45 \mathrm{~km}$ on Kellé Rd., 4 Aug. 1961, Descoings 8827 (P, WAG).

HABITAT. Forest; $250-700 \mathrm{~m}$ alt.

CONSERVATION STATUS. An assessment of the conservation status for Haplocoelum gabonicum was performed using the ArcView tool developed by the GIS-unit of Kew (Moat 2007). Its extent of occurrence measures c. $62,750 \mathrm{~km}^{2}$, which is not much over the unofficial threshold for Near Threatened for this criterion, so it is assessed as possible Near Threatened. The area of occupancy was calculated using a sliding scale, which resulted in a cell width of $47.7 \mathrm{~km}$. The nine resulting grid cells have a total area of $20,500 \mathrm{~km}^{2}$, which gives the conservation assessement as Least Concern. Given both assessement measures more or less result in Least Concern, and the forest in Gabon is, at present, being not severely threatened, I consider that this species should be classified as Least Concern (LC) following the IUCN (2001) catgories and criteria.

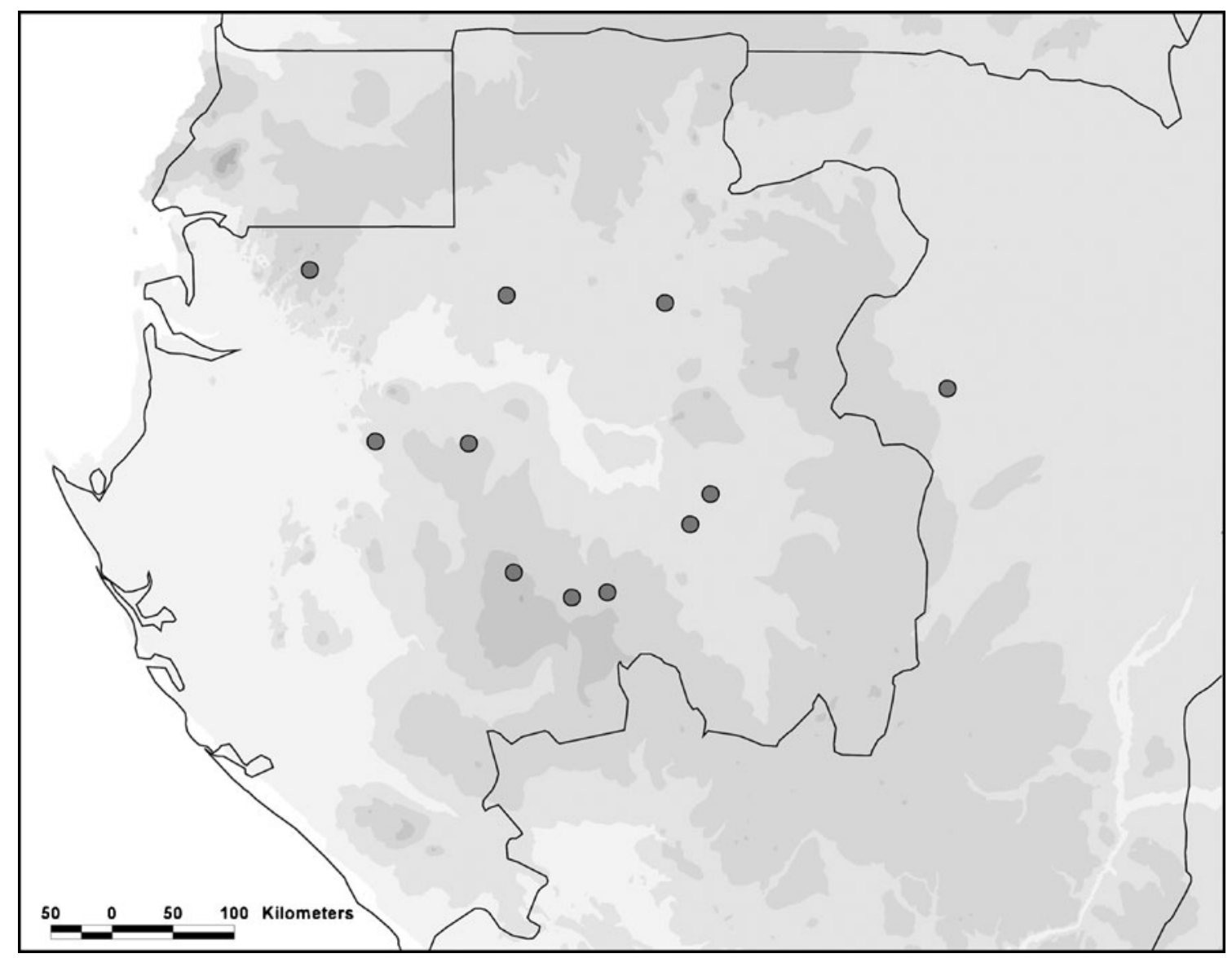

Map 1. Distribution of Haplocoelum gabonicum. 
NOTES. The material cited above bears male flowers only or is sterile. It is likely that Haplocoelum gabonicum is dioecious like the other species of the genus.

The distinction between Haplocoelum gabonicum on the one hand and $H$. acuminatum and $H$. congolanum on the other hand has been laid out in the key below. The latter two species are separated collectively under H. acuminatum as I have not been able to distinguish these two species from one another. Hauman (1960) separated them on account of several variable characters from the inflorescence, namely being 'multiflorous' or 'pluriflorous', pedicel length, the length of the sepals, and the length of the pedicel in fruit. The measurements of $H$. acuminatum given for the last three elements partly contradict with their length in the accompanying illustration. Moreover, the flowering material of $H$. congolanum is very scarce and the leaves do not show any distinctive characters. The habit characteristics, namely shrub or subshrub for $H$. congolanum versus arborescent for $H$. acuminatum, mentioned by Hauman (1958), are not repeated in his key in 1960 (Hauman 1960). For these reasons $H$. congolanum is treated here as a synonym of $H$. acuminatum.

Leaf rachis narrowly winged or marginated (Fig. 1J), without a rudimentary pair of leaflets at base; acumen of leaflets bilobed apically. Congo (Kinshasa), Angola . . . . . . . . . Haplocoelum acuminatum Leaf rachis terete to semiterete (Fig. 1C), with a rudimentary pair of leaflets at base (Fig. 1B); acumen of leaflets rounded to acute apically. Gabon, Congo (Brazzaville) . . . . . . . . . Haplocoelum gabonicum

The holotype of Haplocoelum acuminatum was lost in B. Engler (1921) referred to it by citing its origin and vernacular name but not its collector. Radlkofer (1932) cited Marques 210 as the type, from the same locality and with the same vernacular name as Engler did. He also mentioned that the specimen was obtained from the Coimbra herbarium. Exell \& Mendonça (1954) cited the same collection from LISU. This latter material, on loan at WAG., has been designated lectotype.

Haplocoelum acuminatum is variously cited with the following authorship: Radlk. ex Engl. \& Drude (Exell \& Mendonça (1954)), Radlk. in Engl. (Hauman 1960), or Radkl. (Fouilloy \& Hallé 1973) The manuscript name by Radlkofer was validated by Engler and by him alone in 1921. Therefore the correct authorship is Radkl. ex Engl.

Haplocoelum acuminatum Radkl. ex Engl. (1921 : 278). Type: Angola, Lunda, in Lovo R. valley, Dec. 1885, Marques 210 (holotype $\mathrm{B} \uparrow$; lectotype LISU, selected here).

H. congolanum Hauman (1958: 104). Type: Congo (Kinshasa), Isalowe, April 1939, Louis 14670 (holotype BR), synon. nov.

After the exclusion of the species from Madagascar on molecular evidence, it remains to be seen if the remaining continental species including Haplocoelum gabonicum, constitute a monophyletic entity as is expected by this author on morphological grounds.

\section{Acknowledgements}

H. de Vries is gratefully acknowledged for the fine illustration and R. H. M. J. Lemmens for the translation of the species diagnosis into Latin. I am very grateful to my wife B. J. M Breteler-Klein Breteler for the preparation and correction of the electronic version of the manuscript and to J. J. Wieringa for the assessement of the conservation status of the new species.

\section{References}

Buerki, S., Forest, F., Acevedo-Rodriguez, P., Callmander, M. W., Nylander, J. A. A., Harrington, M., Sanmartin, I., Küpfer, P. \& Alvarez, N. (2009). Plastid and nuclear DNA markers reveal intricate relationships at subfamilial and tribal levels in the soapberry family (Sapindaceae). Molec. Phylogenet. Evol. 51: 238 - 258.

Capuron, R. (1969). Révision des Sapindacées de Madagascar et des Comores. Mém. Mus. Natl. Hist. Nat. n.s., B bot. 19: 1 - 189.

Engler, A. (1921). Die Vegetation der Erde IX: die Pflanzenwelt Afrikas ins besondere seiner tropischen Gebiete III 2: 278. Engelmann, Leipzig.

Exell, A. W. \& Mendonça, F. A. (1954). Sapindaceae In: A. W. Exell \& F. A. Mendonça (eds), Conspectus Florae Angolensis 2: 72 - 93. Ministerio do Ultramar, Junta de Investgaçôes do Ultramar, Lisboa.

Fouilloy, R. \& Hallé, N. (1973). Sapindaceae. In: A. Aubréville \& J. F. Leroy (eds), Flore du Gabon 23: 1 202. Museum National d' Histoire Naturelle, Paris.

Harrington, G. M., Edwards, K. J., Johnson, S. A., Chase, M. W. \& Gadek, P. A. (2005). Phylogenetic inference in Sapindaceae sensu lato using plastid $m a t K$ and $r b c L$ DNA Sequences. Syst. Bot. 30: 366 - 382. 
Hauman, L. (1958). Quelques Sapindaceés du Congo Belge. Bull. Jard. Bot. État Bruxelles 28: $93-109$.

(1960). Sapindaceae. In: A. Robyns (ed.), Flore du Congo Belge et du Ruanda-Urundi 9: 279 384. I.N.E.A.C., Bruxelles.

IUCN (2001). IUCN Red List Categories and Criteria: Version 3.1. IUCN Species Survival Commission. IUCN, Gland, Switzerland \& Cambridge, UK.
Moat, J. (2007). Conservation assessment tools extension for ArcView 3.x, version 1.2. GIS Unit, Royal Botanic Gardens, Kew.

Radlkofer, L. (1932). Sapindaceae. In: A. Engler, Das Pflanzenreich IV. 165, 1: 1 - 1018. Wilhelm Engelmann, Leipzig.

Verdcourt, B. (1998). Haplocoelum. In: H. J. Beentje (ed.), Flora of Tropical East Africa, Sapindaceae, pp. 43 - 47. A. A. Balkema, Rotterdam, Brookfield. 